\title{
Comparative Evaluation of some Physical and Biochemical Quality Attributes of Cocoa Beans Produced in Assin Fosu, Assin Bereku and Nkawie Cocoa Districts of Ghana
}

\author{
Bonaventure Kissinger Maalekuu ${ }^{1} \&$ Nicholas Teye ${ }^{2}$ \\ ${ }^{1}$ Department of Horticulture, Kwame Nkrumah University of Science and Technology, Kumasi, Ghana \\ ${ }^{2}$ Quality Control Company Limited, Ghana Cocoa Board, Kaase Inland port, Kumasi, Ghana \\ Correspondence: Bonaventure Kissinger Maalekuu, Department of Horticulture, Kwame Nkrumah University of \\ Science and Technology, Kumasi, Ghana. Tel: 233-242-769-627. E-mail: kbmaalekuu.agric@knust.edu.gh \\ Nicholas Teye, Quality Control Company Limited, Ghana Cocoa Board, Kaase Inland Port, Kumasi, Ghana. Tel: \\ 233-244-170-002. E-mail: isnicho900@ yahoo.com
}

Received: May 17, 2017

doi:10.5539/jas.v9n12p169
Accepted: June 30, 2017 Online Published: November 15, 2017

URL: https://doi.org/10.5539/jas.v9n12p169

\begin{abstract}
Cocoa contributes significantly to the economy of Ghana due to the premium quality it enjoys in the international market. However, the quality of Ghana cocoa is dwindling gradually making buyers raise serious concerns about the negative impact of poor quality cocoa beans on their products. The study was conducted at Assin Fosu and Assin Bereku cocoa districts in the Central region and Nkawie cocoa district in the Ashanti region. The research was field survey, cut test as well as laboratory work. It was a 3 by 2 factorial experiment in completely randomized design with three replications. There were two factors: the first consisted of the various locations (districts) the study was conducted whilst the second factor comprised the varieties of cocoa (Amelonado and 'Akokorabedi') obtained from the various locations. The survey report showed that there were differences in postharvest practices by farmers such as turning during fermentation and duration of fermentation. A report from the cut test revealed that the interaction effect between cocoa varieties and the locations were of significant difference for percentage mouldy cocoa beans $(p=0.00)$ and slaty cocoa beans $(p=0.05)$ at $5 \%$ probability level. For percentage mouldy beans, Assin Fosu District (location) recorded the highest (2.57\%) mean value whilst Nkawie cocoa district (location) recorded the least $(0.89 \%)$. Similarly, the interaction effect between cocoa varieties and the locations for percentage free fatty acid content $(p=0.01)$ and $\mathrm{pH}(p=0.00)$ was significantly different at $1 \%$ probability level. Assin Fosu District (location) recorded the highest (1.22\%) mean percentage free fatty acid value whilst Nkawie district (location) registered the least (1.15\%). For pH, Nkawie District (location) recorded the highest (5.82) whilst Assin Fosu district (location) registered the least (5.50). Generally, cocoa beans from the various locations (districts) were of good quality since they all fell within the range of Quality Control Company Limited quality standards, however, beans from Nkawie cocoa district were rated as the best in terms of physical and biochemical quality attributes of the beans.
\end{abstract}

Keywords: mould, slate, insect damage, germinated, fat, $\mathrm{pH}$, free fatty acid, moisture content

\section{Introduction}

The cocoa industry is being faced with the problems of defective and inferior cocoa beans over the years (Afoakwa et al., 2010). The presence of these defects in the cocoa tends to reduce the quality of the cocoa beans. Some License Buying Companies have their cocoa rejected on these defects if it falls beyond the permissible level. These cause them time, space, logistics, labour cost and other resources in reconditioning their rejected consignments (Duguma et al., 2001). There are instances where cocoa change from its original grade to sub-standard due mainly to the presence of some defective beans.

Despite various interventions by players in the cocoa industry, particularly Quality Control Company Limited to clamp down the presence of these defective beans some cocoa districts still record high percentage of poor quality cocoa beans (Amoa-Awua et al., 2007). 
Both local and foreign buyers have been raising serious concerns about the negative impact of poor quality cocoa beans on their products.

The implication is that they tend to pay less for the produce since it did not meet their quality specification or requirement. This invariably robs the country of her GDP (Canatus \& Aikins, 2009).

Dried cocoa beans can absorb moisture if the humidity is high. If the moisture content rises above $8 \%$, mould may develop inside the beans. At $8 \%$ moisture, cocoa beans are in equilibrium with the ambient relative humidity (about 70\%) and normal temperatures in the tropics. Where the relative humidity exceeds this level for prolonged periods there is the danger of internal mould development, which will eventually affect the quality of the cocoa beans (Wood \& Lass, 1985).

Postharvest activities such as harvesting of pods, pods storage, pods breaking, fermentation, drying and storage of cocoa beans when done wrongly could reduce the quality of the cocoa beans thereby affecting the market price of the produce (Fowler, 2009). Various stakeholders in the cocoa industry including Quality Control Company Limited, License Buying Companies, Transporters and Cocoa farmers all have part to play in ensuring the quality of Ghana cocoa beans, which is the benchmark of the world cocoa.

The study hence aimed to investigate into and ascertain the postharvest practices that affect the quality of cocoa beans and suggest appropriate measures that will help reduce such practices.

\section{Materials and Methods}

\subsection{Survey}

A survey was conducted in five communities at each of the respective districts.

The data from the field survey were collected using structured questionnaire to obtain primary data from the respondents (farmers). In each of the cocoa Districts selected for the study, 50 cocoa farmers were interviewed from 5 different communities within each district making a total of 150 farmers and 15 farming communities. Visits were also made to Quality Control Company Limited of Ghana Cocoa Board at each of the respective Districts to seek their opinion on the postharvest practices that affect the quality of cocoa beans and what could be done to minimize such practices.

The activities of five cocoa farmers from each of the Districts who indicated to have recorded some amount of defective beans (poor quality beans) in their cocoa and those who do not record any according to the questionnaire administered were monitored through the various postharvest practices: harvesting of the pods, gathering, pods breaking, fermentation, drying and bagging. The activities of these two groups of farmers were compared to identify differences in their procedures.

\subsection{Cut Test Analysis}

Random samples of dried cocoa beans were taken from bags of five cocoa farmers from each district and the beans were examined to obtain information on the physical beans quality characteristics such as mouldy beans, slaty beans, insect damaged beans, germinated beans and percentage purity using the cut test procedure employed by Quality Control Company Limited. The beans selected were bulked and quartered to ensure that the beans were uniformly mixed after which 300 of the beans were cut lengthwise with a cutting knife and visually observed for any defects.

Figure 1 shows physical beans quality characteristics.

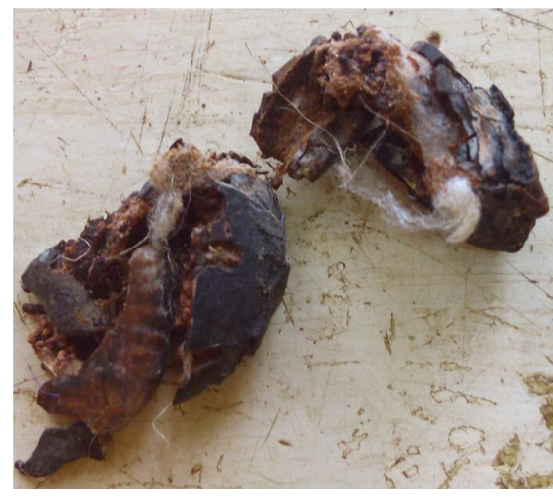

Insect damaged Cocoa Beans

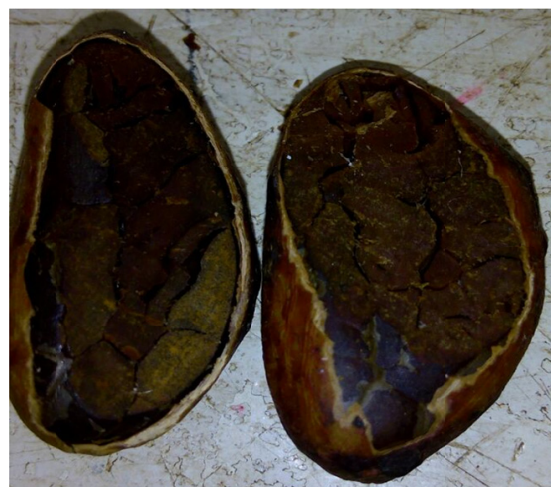

Brown Cocoa Beans 


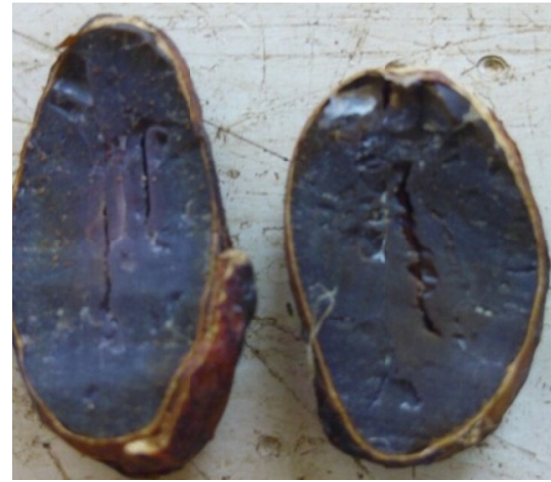

Slaty Cocoa Beans

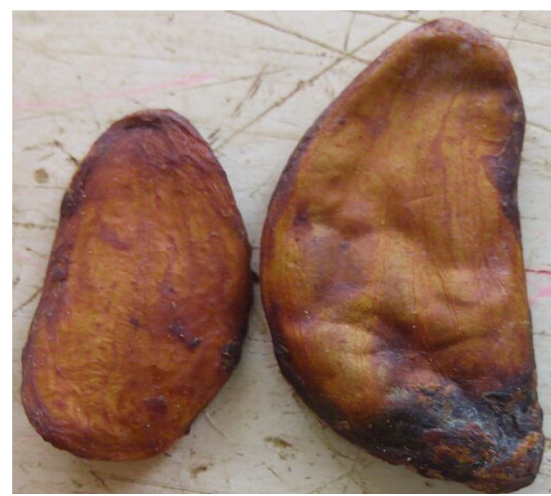

Flat Cocoa Beans

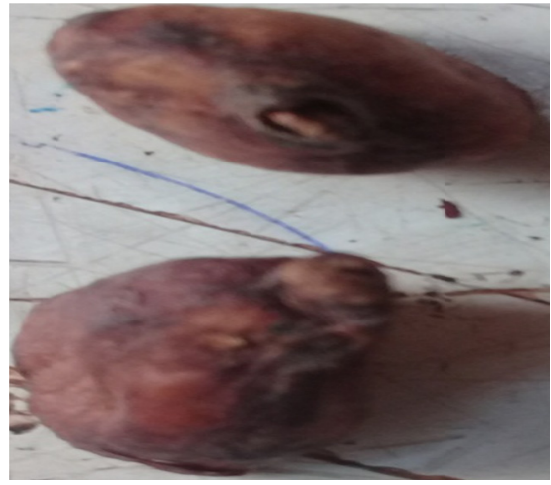

Germinated Cocoa Beans

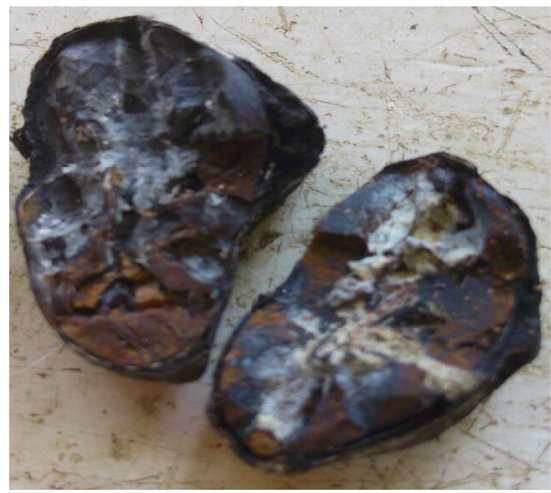

Mouldy Cocoa Beans

Figure 1. Cut test showing physical beans quality characteristics

\subsection{Laboratory Work}

Hundred grams $(100 \mathrm{~g})$ each of 'Akokorabedi' and Amelonado cocoa beans were examined to ascertain the chemical quality characteristics such as Fat content, free fatty acid content, moisture content and $\mathrm{pH}$.

\subsubsection{Determination of $\mathrm{pH}$}

A pH meter was calibrated at $20{ }^{\circ} \mathrm{C}$ using two buffers ( $\mathrm{pH} 4.00$ and 7.00 ). 40 grams of powdered cocoa beans was weighed into $100 \mathrm{ml}$ beaker. While stirring slowly, $60 \mathrm{mls}$ of boiling distilled water with a graduated cylinder was added to the ground nib. The mixture was left to cool in a cold bath, while it was stirred occasionally. The $\mathrm{pH}$ was measured when the suspension had cooled to $20^{\circ} \mathrm{C}$. The measurements were performed in triplicate (AOAC, 2005) method 963.15.

\subsubsection{Determination of Fat Content}

Fat content was determined using the AOAC (2005) method 963.15.

Samples of cocoa beans were milled and mixed thoroughly. 2 grams of the sample was weighed and placed in a filter paper fold. A Piece of filter paper was folded to hold the sample. A second filter paper was wrapped around and left opened at the top like a thimble. A piece of cotton wool was placed at the top, which evenly distributed the solvent as it dropped on the sample during extraction. The sample packet was placed in the butt tubes of the Soxhlet extraction apparatus. The extraction flask was placed in an oven for about 5 minutes at $110{ }^{\circ} \mathrm{C}$ and it was then cooled and weighed. The fat was extracted with petroleum ether for 2-3 hours without interruption by gentle heating. It was then allowed to cool and the extraction flask dismantled. The ether was evaporated on a water bath until no colour of ether remained. It was then cooled at room temperature. The extraction flask and its extract were re-weighed and the weight recorded. 
Calculations:

$(\mathrm{A}+\mathrm{B})-\mathrm{A}=\mathrm{B}$

$\%$ ether extract $=\mathrm{B} / \mathrm{C} \times 100$

Where, $\mathrm{A}=$ weight of flask; $\mathrm{B}=$ weight of ether extract; $\mathrm{C}=$ weight of sample.

\subsubsection{Determination of Free Fatty Acid (FFA)}

Fat from the sample was extracted with petroleum ether $\left(40-60{ }^{\circ} \mathrm{C}\right)$ in a Soxhlet apparatus using the AOAC (2005) method 963.15. FFA of the oil extracted was determined using the IOCCC (1996) method 42-1993. 5 grams of the oil was weighed into a dry $250 \mathrm{ml}$ stoppered conical flask and $25 \mathrm{ml}$ of $95 \%$ ethanol/diethyl ether (1:1) and few drops of phenolphthalein indicator were added. The solution was titrated with $0.1 \mathrm{M} \mathrm{KOH}$ by swirling constantly until a faint pink colour persisted for 30 seconds. The percentage FFA was determined and the analysis was conducted in triplicates, and the mean value recorded.

Calculations:

Acid Value $=\frac{-56.1 \times \mathrm{T} \times \mathrm{V}}{\mathrm{W}}$

Where, $\mathrm{T}=$ Concentration of Standardized $\mathrm{KOH}=0.1 \mathrm{M} ; \mathrm{V}=$ Volume of $\mathrm{KOH}$ used in $\mathrm{ml}$ (Titre value); $\mathrm{W}=$ Weight of fat sample $(\mathrm{g})$.

Free Fatty Acid $=\frac{\text { Acid Value }}{\mathrm{M}}$

Where, $\mathrm{M}=$ Molecular weight of fat sample; $\mathrm{M}=2.82$.

\subsubsection{Determination of Moisture Content}

Moisture content of the beans was determined using the AOAC (2005) method 963.15.

A moisture can was weighed and 2 grams of granular sample was weighed. This was allowed to dry overnight in an air oven at $110^{\circ} \mathrm{C}$ for 24 hours. The can plus the sample was cooled in desiccators and re-weighed.

Calculations:

$(\mathrm{A}+\mathrm{B})-\mathrm{A}=\mathrm{B}$

$(\mathrm{A}+\mathrm{B})-(\mathrm{A}+\mathrm{C})=\mathrm{B}-\mathrm{C}=\mathrm{D}$

$\%$ Moisture $=\mathrm{D} / \mathrm{B} \times 100$

Where, $\mathrm{A}=$ can wt.; $\mathrm{B}=$ sample wt.; $\mathrm{C}=$ dry sample wt.; $\mathrm{D}=$ moisture wt.

\subsection{Parameters}

Factors such as mouldy beans, slate, insect damaged beans, germinated as well as flat beans were examined through cut test and physically counted each defective beans and expressed each defective type of beans as a percentage. Additionally, chemical qualities of the beans were also measured.

\subsection{Data Analysis}

Data that were received from the field survey were analysed with Excel graph and IBM Statistical Product and Service Solution (SPSS) version 21. The laboratory and cut test results were analysed using student statistics version 9 software to perform ANOVA. Treatment means were separated with LSD at $1 \%$ probability level $(p=$ $0.01)$ for the laboratory work and LSD at $5 \%(p=0.05)$ probability level for the cut test result.

\section{Results and Discussion}

\subsection{Field Survey}

\subsubsection{Intervals for Harvesting Cocoa Pods by Farmers during the Main Season}

Generally, in all the locations, the intervals for harvesting cocoa pods by farmers indicated that $48.7 \%$ of the respondents (farmers) harvest their cocoa pods fortnightly whilst $32.6 \%$ indicated they harvest their cocoa pods monthly. It was observed that $18 \%$ of the respondents harvest their cocoa every three weeks.

\subsubsection{Objects Used in Breaking Cocoa Pods by Farmers}

The survey report showed that $72 \%$ of the respondents (farmers) in all the locations break their cocoa pods with blunt objects whilst $28 \%$ of the respondents break theirs with sharp objects. Using blunt object would help improve the quality of cocoa beans since the beans would be secured from injury (Osei, 2007). Employing sharp 
objects to break cocoa pods tend to injure the beans, which would provide avenue for insect infection, which would intend reduce the quality of cocoa beans (Thery, 1995).

Figures two and three show intervals for harvesting cocoa pods during the major season and objects used to break cocoa pods by farmers respectively.

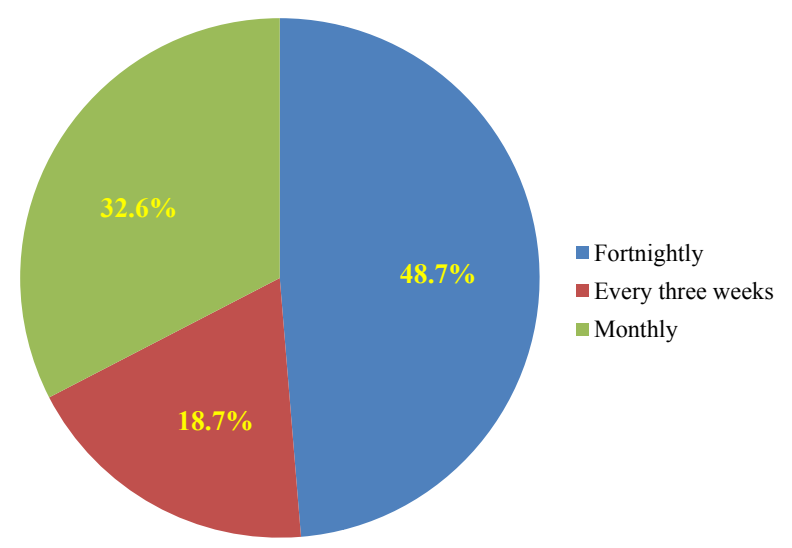

Figure 2. Intervals for harvesting cocoa pods during the major season by farmers

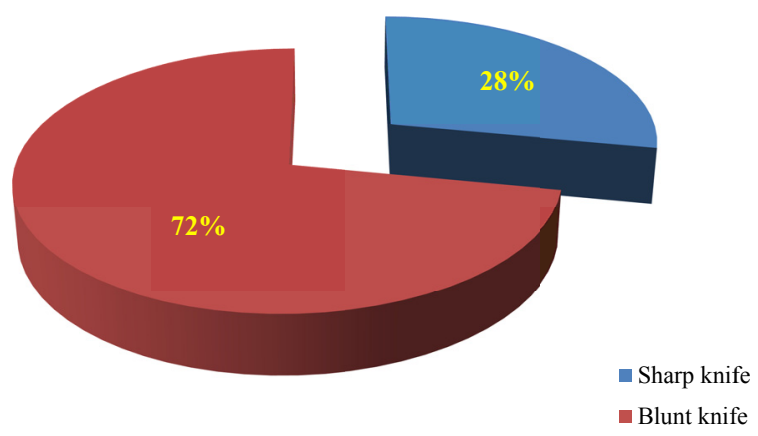

Figure 3. Objects used to break cocoa pods by farmers

\subsubsection{Duration of Fermentation Practiced by Farmers}

The duration of fermentation practiced by farmers showed that $72 \%$ of the respondents (farmers) in Assin Fosu District ferment their cocoa between six and seven days whilst $4 \%$ of the respondents ferment their cocoa for more than seven days. For Assin Bereku and Nkawie Districts, $68 \%$ and $80 \%$ of the respondents respectively ferment their cocoa between six and seven days whilst $8 \%$ and $4 \%$ of the respondents ferment their cocoa for more than seven days respectively.

The duration of fermentation varies according to the variety of cocoa being fermented, however, it is between five and seven days but the optimal duration is six days (Camu et al., 2008). Fermentation of cocoa contributes immensely to the quality of cocoa beans. Greater percentage of respondents in all the districts indicated they ferment their cocoa for a period of between six and seven days. However, Nkawie cocoa district recorded the highest percentage of respondents that said they ferment their cocoa within the recommended practice. This is a good sign of enhancing cocoa beans quality. The significance of cocoa fermentation is to develop chocolate precursors in the beans (Pandey et al., 2011).

Table one shows duration of fermentation practiced by farmers. 
Table 1. Duration of fermentation practiced by farmers

\begin{tabular}{|c|c|c|c|c|c|c|}
\hline \multirow{2}{*}{ Duration of fermentation } & \multicolumn{2}{|c|}{ Assin Fosu } & \multicolumn{2}{|c|}{ Assin Bereku } & \multicolumn{2}{|c|}{ Nkawie } \\
\hline & Freq. & $\%$ & Freq. & $\%$ & Freq. & $\%$ \\
\hline 4-5 days & 12 & 24 & 12 & 24 & 8 & 16 \\
\hline 6-7 days & 36 & 72 & 34 & 68 & 40 & 80 \\
\hline Above 7 days & 2 & 4 & 4 & 8 & 2 & 4 \\
\hline Total & 50 & 100 & 50 & 100 & 50 & 100 \\
\hline
\end{tabular}

\subsubsection{Turning of Cocoa Beans during Fermentation by Farmers}

It was observed that none of the respondents in Assin Fosu and Assin Bereku Districts practice turning during fermentation. However, 24\% of respondents in Nkawie District indicated they do turn their cocoa beans during fermentation. Failure to turn cocoa beans during fermentation could affect the quality of cocoa beans. In enhancing and achieving cocoa beans quality, turning plays significant role in fermentation (Fowler, 2009). Among the reasons stated for not turning included: distance from house to farm is far, do not have time to do it and not aware of the practice. This therefore would mean that cocoa beans from Nkawie District would be of good quality compared to their counterparts in Assin Fosu and Assin Bereku Districts. Turning of cocoa beans aerates the fermenting mass to avoid uneven temperature and oxygen distributions, which intend improve the quality of cocoa beans (Fowler, 1995).

Table two below shows turning of cocoa beans during fermentation by farmers.

Table 2. Turning of cocoa beans during fermentation by farmers

\begin{tabular}{|c|c|c|c|c|c|c|}
\hline \multirow{2}{*}{$\begin{array}{l}\text { Turning of cocoa beans } \\
\text { during fermentation }\end{array}$} & \multicolumn{2}{|c|}{ Assin Fosu } & \multicolumn{2}{|c|}{ Assin Bereku } & \multicolumn{2}{|c|}{ Nkawie } \\
\hline & Freq. & $\%$ & Freq. & $\%$ & Freq. & $\%$ \\
\hline Yes & 0 & 0 & 0 & 0 & 12 & 24 \\
\hline No & 50 & 100 & 50 & 100 & 38 & 76 \\
\hline Total & 50 & 100 & 50 & 100 & 50 & 100 \\
\hline
\end{tabular}

\subsection{Physical Beans Quality Characteristics}

The effect of cocoa varieties on percentage mouldy, slaty, germinated, flat, insect damaged and purity cocoa beans of dried cocoa beans showed that significant differences occurred between Amelonado and Hybrid cocoa varieties for mouldy, slaty, flat, insect damaged and purity cocoa beans. Hybrid cocoa variety recorded the highest $(92.80 \%)$ purity cocoa beans than Amelonado, which recorded a purity value of $91.90 \%$. Wood and Lass (1985) reported that factors such as slow or inadequate drying of cocoa beans, prolonged fermentation as well as storage of dried cocoa beans under highly humid conditions could lead to mouldy cocoa beans. The authors added that germinated and damaged beans are also prone to becoming mould. Mould produces mycotoxins particularly Ochratoxin 'A' which gives cancer when one consumes any cocoa product. They also cause high level of free fatty acid thereby given the cocoa a bad flavour (Afoakwa et al., 2010).

The cut test result showed that Assin Bereku District registered the highest $(4.22 \%)$ slaty beans with the least being recorded by Nkawie District (1.72\%). The high slaty value recorded by Assin Bereku District could be due to the fact that the farmers do not practice turning during fermentation as realized in the survey. However, this figure was within the permissible level of not more than $8 \%$ to be of good quality cocoa beans. Slaty cocoa beans give chocolate a bitter taste and reduce the market value of cocoa (Dand, 1997). Factors that attribute to slaty cocoa beans include lack of fermentation, inadequate fermentation days, lack of turning during fermentation, insufficient fermentation heap size and when the temperature outside the fermentation mass is too low especially during harmattan period (Daviron, 1995).

In terms of variety, Amelonado recorded the highest percentage slaty beans $(3.5 \%)$, flat $(0.92 \%)$ and insect damaged beans $(0.97 \%)$ than hybrid. This could be due to the inherent quality characteristics such as resistance to pests and diseases, ability to withstand extremes of weather and early maturity possessed by the hybrid variety as reported by Osei (2007).

The mean percentage mouldy beans for the interaction ranged from $0.89 \%$ to $2.57 \%$. Nkawie district recorded the least (0.89\%) mouldy beans whilst Assin Fosu District recorded the highest $(2.57 \%)$. 
Tables 3, 4 and 5 show physical quality characteristics of cocoa beans.

Table 3. Cocoa varieties and locations on percentage mouldy, slaty and purity cocoa beans

\begin{tabular}{llll}
\hline Interaction & Mouldy Cocoa Beans & Slaty Cocoa Beans & Purity Cocoa Beans \\
\hline Assin Fosu $\times$ Amelonado & $2.57^{\mathrm{a}}$ & $4.20^{\mathrm{a}}$ & $90.57^{\mathrm{b}}$ \\
Assin Fosu $\times$ Hybrid & $2.57^{\mathrm{a}}$ & $3.33^{\mathrm{a}}$ & $91.10^{\mathrm{b}}$ \\
Assin Bereku $\times$ Amelonado & $2.53^{\mathrm{a}}$ & $4.43^{\mathrm{a}}$ & $90.23^{\mathrm{b}}$ \\
Assin Bereku $\times$ Hybrid & $2.20^{\mathrm{a}}$ & $4.00^{\mathrm{a}}$ & $91.20^{\mathrm{b}}$ \\
Nkawie $\times$ Amelonado & $2.07^{\mathrm{a}}$ & $1.87^{\mathrm{c}}$ & $94.90^{\mathrm{a}}$ \\
Nkawie $\times$ Hybrid & $0.67^{\mathrm{b}}$ & $2.97^{\mathrm{bc}}$ & $96.10^{\mathrm{a}}$ \\
\hdashline LSD (0.05) & 0.95 & 1.45 & 1.78 \\
CV (\%) & 9.68 & 7.90 & 0.77 \\
\hline
\end{tabular}

Table 4. Percentage mouldy, slaty, germinated, flat, insect damaged beans and purity cocoa beans

\begin{tabular}{lllllll}
\hline Varieties & Mould & Slate & Germinated & Flat & Insect damaged & Purity \\
\hline Amelonado & $2.07^{\mathrm{a}}$ & $3.5^{\mathrm{b}}$ & $0.74^{\mathrm{a}}$ & $0.92^{\mathrm{a}}$ & $0.97^{\mathrm{a}}$ & $91.90^{\mathrm{b}}$ \\
Akokorabedi & $1.81^{\mathrm{c}}$ & $2.97^{\mathrm{b}}$ & $0.81^{\mathrm{a}}$ & $0.70^{\mathrm{c}}$ & $0.89^{\mathrm{ab}}$ & $92.80^{\mathrm{a}}$ \\
\hline CV (\%) & 9.68 & 7.96 & $5.27^{\mathrm{b}}$ & 5.44 & 9.04 & 0.77 \\
LSD (5\%) & 0.12 & 0.46 & 0.60 & 0.08 & 0.61 & 0.84 \\
\hline
\end{tabular}

Table 5. Percentage mouldy, slaty, germinated, flat, insect damaged and purity cocoa beans

\begin{tabular}{lllllll}
\hline Location & Mould & Slate & Germinated & Flat & Insect damaged & Purity \\
\hline Assin Fosu & $2.57^{\mathrm{a}}$ & $3.77^{\mathrm{a}}$ & $1.00^{\mathrm{a}}$ & $0.95^{\mathrm{a}}$ & $0.88^{\mathrm{b}}$ & $90.83^{\mathrm{c}}$ \\
Assin Bereku & $2.37^{\mathrm{a}}$ & $4.22^{\mathrm{a}}$ & $0.83^{\mathrm{a}}$ & $0.77^{\mathrm{b}}$ & $1.07^{\mathrm{a}}$ & $90.72^{\mathrm{c}}$ \\
Nkawie & $0.88^{\mathrm{b}}$ & $1.72^{\mathrm{b}}$ & $0.50^{\mathrm{a}}$ & $0.72^{\mathrm{b}}$ & $0.83 \mathrm{~b}$ & $95.50^{\mathrm{a}}$ \\
\hline CV (\%) & 9.68 & 7.96 & 5.27 & 5.44 & 9.04 & 0.77 \\
LSD (5\%) & 0.67 & 1.02 & 0.73 & 0.12 & 0.12 & 1.25 \\
\hline
\end{tabular}

\subsection{Chemical Beans Quality Characteristics}

The effect of locations on fat, FFA, $\mathrm{pH}$, and moisture content of dried cocoa beans revealed that significant deference was observed between the locations and varieties for $\mathrm{pH}$ and free fatty acid content (FFA). For fat, Assin Bereku District registered the highest value (43.53\%) whilst Assin Fosu District recorded the least $(42.65 \%)$. In the case of free fatty acid content, Assin Fosu District recorded the highest value of $1.22 \%$ with the least value being registered by Nkawie District (1.05\%). Free fatty acid occurs because of poor postharvest activities such as the use of black beans from diseased pods, the use of mouldy beans, germinated beans from over ripened pods and the inclusion of decayed beans (Daviron, 1995). Prolonged storage of cocoa beans could also cause an increase in the free fatty acid level of dried cocoa beans. The results further showed that Assin Fosu District registered the highest (1.22\%) value of free fatty acid (FFA) with Nkawie District recording the least $(1.15 \%)$. However, the values recorded were within the European Union requirement of $1.75 \%$ to be of good quality cocoa beans (Fowler, 2009).

As per Quality Control Company Limited quality standard, any parcel of cocoa with moisture content above $7.5 \%$ is not acceptable. Moisture contents exceeding $8 \%$ could lead to mould development inside the beans during subsequent storage and transport. Additionally, cocoa beans with high moisture content could cause beans to germinate under favorable conditions, cause beans to decay and insect infestation. All these factors contribute to high level of free fatty acid, which invariably affects the quality of cocoa beans (Fowler, 2009).

Tables 6,7 and 8 below provide chemical quality characteristics of cocoa beans. 
Table 6. Interaction of cocoa varieties and locations on $\mathrm{pH}$ and percentage free fatty acid content of dried cocoa beans

\begin{tabular}{lll}
\hline Interaction & $\mathbf{p H}$ & Free Fatty Accid (FFA) \\
\hline Assin Fosu $\times$ Amelonado & $5.83^{\mathrm{a}}$ & $1.36^{\mathrm{a}}$ \\
Assin Fosu $\times$ Akokorabedi & $5.47^{\mathrm{b}}$ & $1.07^{\mathrm{ab}}$ \\
Assin Bereku $\times$ Amelonado & $5.77^{\mathrm{a}}$ & $1.07^{\mathrm{ab}}$ \\
Assin Bereku $\times$ Akokorabedi & $5.67^{\mathrm{ab}}$ & $1.28^{\mathrm{ab}}$ \\
Nkawie $\times$ Amelonado & $5.80^{\mathrm{a}}$ & $1.18^{\mathrm{ab}}$ \\
Nkawie $\times$ Akokorabedi & $5.52^{\mathrm{b}}$ & $0.97^{\mathrm{b}}$ \\
\hline LSD $(0.01)$ & 0.24 & 0.38 \\
CV $(\%)$ & 1.71 & 13.18 \\
\hline
\end{tabular}

Table 7. Cocoa varieties on fat, FFA, $\mathrm{pH}$ and moisture content of dried cocoa beans

\begin{tabular}{lllll}
\hline Variety & Fat (\%) & FFA (\%) & pH & Moisture (\%) \\
\hline Amelonado & $42.77^{\mathrm{a}}$ & $1.18^{\mathrm{a}}$ & $5.80^{\mathrm{a}}$ & $7.99^{\mathrm{a}}$ \\
Akokorabedi & $43.56^{\mathrm{a}}$ & $1.11^{\mathrm{c}}$ & $5.54^{\mathrm{b}}$ & $7.64^{\mathrm{a}}$ \\
\hdashline CV (\%) & 3.75 & 13.18 & 1.71 & 3.44 \\
LSD (1\%) & 2.33 & 0.02 & 0.14 & 0.67 \\
\hline
\end{tabular}

Table 8. Locations on fat, FFA, pH and moisture content of dried cocoa beans

\begin{tabular}{lllll}
\hline Locations & Fat (\%) & FFA (\%) & pH & Moisture (\%) \\
\hline Assin Fosu & $42.65^{\mathrm{a}}$ & $1.22^{\mathrm{a}}$ & $5.65^{\mathrm{c}}$ & $7.90^{\mathrm{a}}$ \\
Assin Bereku & $43.53^{\mathrm{a}}$ & $1.18^{\mathrm{b}}$ & $5.67^{\mathrm{b}}$ & $7.80^{\mathrm{a}}$ \\
Nkawie & $43.30^{\mathrm{a}}$ & $1.05^{\mathrm{c}}$ & $5.70^{\mathrm{a}}$ & $7.60^{\mathrm{a}}$ \\
\hdashline CV (\%) & 3.75 & 13.18 & 1.71 & 3.44 \\
LSD (1\%) & 2.86 & 0.03 & 0.02 & 0.47 \\
\hline
\end{tabular}

\section{Conclusion}

Respondents (farmers) from the various locations exhibited differences in some postharvest practices such as duration of fermentation and turning of cocoa mass during fermentation.

Generally, cocoa beans from the various locations (districts) were of good quality since they all fell within the range of Quality Control Company Limited quality standards, however, beans from Nkawie cocoa district were rated as the best in terms of physical and biochemical quality attributes of the beans.

There were significant differences between cocoa varieties and the different locations for their percentage mould, slate, flat, insect damaged and purity cocoa beans.

For percentage mouldy cocoa beans, Assin Fosu District recorded the highest value of $2.57 \%$ whilst Nkawie District registered the least $(0.89 \%)$. Assin Bereku District recorded the greatest percentage of slaty cocoa beans (4.22\%) with Nkawie District registering the least (1.72\%).

The interaction effect between cocoa varieties and the locations for free fatty acid content and $\mathrm{pH}$ were of significant difference. Assin Fosu District registered the highest free fatty acid content of $1.22 \%$ whilst Nkawie District recorded the least (1.15). For pH, Nkawie District recorded the highest value of 5.82 with the least value of 5.50 being registered by Assin Fosu District.

\section{Recommendations}

It is suggested that further studies be conducted at other cocoa Districts in order to identify the postharvest practices of cocoa farmers that affect quality.

In addition, pesticide residue should be carried out to determine the maximum residue levels and types of pesticides used by farmers at the various locations.

\section{Acknowledgements}

The authors are most grateful to everyone who has played a significant role in carrying out this research: those who monitored and collected the data, those who analysed the data, those who provided secretarial work and 
those who reviewed the manuscript. Their individual contributions are immensely appreciated. Special thanks also go to the publisher for providing time and space to publish this article to the benefit of the public.

\section{References}

Afoakwa, E. O., \& Paterson, A. (2010). Cocoa fermentation: Chocolate flavour quality. Encyclopedia of biotechnology in agriculture and food (pp. 457-468). Taylor \& Francis Publishing Inc., Oxford, UK. https://doi.org/10.1081/E-EBAF-120045413

Amoa-Awua, W., Madsen, M., Takramah, J. F., Olaiya, A., Ban-Koffi, L., \& Jakobsen, M. (2007). Quality manual for production and processing cocoa. Department of Food Science, University of Copenhagen.

AOAC. (2005). Official methods of analysis (18th ed.). Association of Official Analytical Chemists, Washington, D.C., USA.

Camu, N. A., Gonzalez, T. D., Winter, A. V., Schoor, K. D., Bruyne, P., Vandamme, J. S., Takrama, S. K., \& Addo, L. D. (2008). Influence of turning and environmental contamination on the dynamics of population of acid and acetic acid bacteria involved in spontaneous cocoa bean heap fermentation in Ghana. Applied and Environmental Microbiology, 74(1), 86-96. https://doi.org/10.1128/AEM.01512-07

Canatus, D. A., \& Aikins, D. E. (2009). Reforming Ghana's Cocoa Sector-An Evaluation of Private Participation in Marketing (Master's Thesis, Lulea University of Technology, Sweden). Retrieved January 16, 2011, from http://epubl.ltu.se/1653-0187/2009/044/LTU-PB-EX-09044-SE.pdf

Dand, R. (1997). The international cocoa trade (p. 374). Wood Head Publishing Limited.

Daviron, B. (1995). Economic aspects of quality (pp. 125-134). Cocoa meetings: The various aspect of quality, Seminar proceedings, Montpellier.

Duguma, B., Gochowski, J., \& Bakala, J. (2001). Smallholder cacao (Theobroma cacao Linn) cultivation in agroforestry systems of Westland Central Africa: Challenges and opportunities. Agro. Syst, 51, 177-188. https://doi.org/10.1023/A:1010747224249

Fowler, M. S. (2009). Cocoa Beans: From Tree to Factory. In S. T. Beckett (Ed.), Industrial chocolate manufacture and use (4th ed., pp. 137-152). Wiley- Blackwell Science, Oxford, UK.

Fowler, M. I. S. (1995). Quality of cocoa beans for chocolate manufacturers (pp. 147-153). Cocoa meetings: The various aspect of quality, Seminar Proceedings, Montpellier.

IOCCC. (1996). Determination of free fatty acids (FFA) contents of cocoa nib acidity. Analytical Method No. 42-1993. International Office of Cocoa, Chocolate and Sugar Confectionary Industries.

Osei, I. (2007). Challenges of Quality Standards in the Cocoa Industry. Presentation at the African Cocoa Summit, September 3-5, 2007, Accra, Ghana.

Pandey, A., \& Singh, G. (2011). Development and storage study of reduced sugar soy containing compound chocolate. J. Food Sci. Techno., 48, 76-82. https://doi.org/10.1007/s13197-010-0136-8

Thery, V. (1995). Quality for cocoa powder producers (pp. 155-157). Cocoa meetings: The various aspect of quality, Seminar Proceedings, Montpellier.

Wood, G. A. R., \& Lass, R. A. (1985). Cocoa (4th ed.). Tropical Agricultural Series, Longman Group, London.

\section{Copyrights}

Copyright for this article is retained by the author(s), with first publication rights granted to the journal.

This is an open-access article distributed under the terms and conditions of the Creative Commons Attribution license (http://creativecommons.org/licenses/by/4.0/). 